\title{
Response to Exercise after Bed Rest and after Training : A Longitudinal Study of Adaptive Changes in Oxygen Transport and Body Compo- sition
}

Saltin B, et al : Circulation 1968 ; 38 (5 Suppl) : Vll-1-78

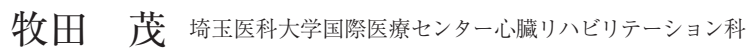

\section{口意義}

今日では廃用予防のために，臥床からできるだ け早期に離床を図りトレーニングに移行すること が重要とされているが, 本研究は Saltin らが, 有 酸素能力と体組成・呼吸循環器系などの総合的な 変化について，長期臥床を続けることがいかに身 体に悪影響を及ぼすかについて，またその後の有 酸素トレーニングの効果を実証した。身体的な脱 調節 (deconditioning) とその回復について長期に わたる詳細なデータを示し, 早期離床と運動療法 についての理論的な妥当性を証明した世界で初の 研究である.

\section{要旨}

19〜21 歳の健康な男子大学生 5 名を対象に, 20 日間のベッド上での生活（ベッドレスト）とそれに 続く 55 日間のインターバルもしくは一定負荷強度 のトレーニングを行い, 有酸素能力と体組成ならび に呼吸循環系の変化を追跡した。 まずベッドレス 卜前後についてであるが, 体重の変化はなく, 除脂 肪体重, 体液量, 赤血球量や血漿量は減少傾向を 示した. 呼吸機能については変化を示さなかった. 最大酸素摂取量は 3.30 から $2.43 \mathrm{~L} / \mathrm{min}$ と $26.4 \%$ も減少した。これは心拍出量 (26.0\%減), 一回拍 出量（28.8\%減）の減少によっていた。 また, 酸素 摂取量 $1.5 \mathrm{~L} / \mathrm{min}$ での負荷における心拍数はベッ ドレスト前が 129 bpm だったのがベッドレスト後 は $164 \mathrm{bpm}$ に上昇した。

トレーニング後における変化について最大酸素 摂取量は $3.41 \mathrm{~L} / \mathrm{min}$ に増加し，特に介入前に活動 的でなかった 3 名については $33 \%$ も増加した。 ま
た,この 3 名の心拍出量は $20.0 \mathrm{~L} / \mathrm{min}$ と $16.5 \%$ 増 加し, 一回拍出量は $105 \mathrm{~mL}$ と $17 \%$ 増加した. さ らに, 動静脈酸素含有量較差が 14.6 から $17.0 \mathrm{~mL} /$ $100 \mathrm{~mL}$ へ $16.5 \%$ 増加した. 一方, スポーツを行っ ていた活動的な 2 名については, 最大酸素摂取量 が $4.65 \mathrm{~L} / \mathrm{min}$ と増加率は $4 \%$ にとどまった。酸素 摂取量 $1.5 \mathrm{~L} / \mathrm{min}$ での負荷における心拍数は $115 \mathrm{bpm}$ に減少したが, スポーツを行っていなかっ た 3 名の減少が $30 \mathrm{bpm}$ と多かった.

\section{口 解説}

「サルチンのベッドレストの研究」として知られ ている 78 ページにわたる論文である，米国におい て 1950 年代までの心臓リハビリテーションは, 心 筋壊死が㓔痕化するまでストレスをかけてはいけ ないという理由で, 急性心筋梗塞発症後 1 力月以 上もベッド臥床を強いられていたのである，その 結果, 身体的, 精神的な脱調節が引き起こされ, 患 者本人はもちろん医療経済的にも社会的にも大き な問題となった. 要するに, 医原性の廃用症候群 が引き起こされていたのである。そその後徐々に早 期離床の試みが開始されていたが, Saltinのこの 研究成果により早期離床の重要性が科学的に明ら かにされたことから，急性期の心臓リハビリテー ションの流れが大きく変わるきっかけとなった。リ ハビリテーションの教科書には常に引用されてい る論文である.この研究から 30 年後にまったく同 じ対象による加齢とトレーニング効果をみた研究 が実施されたのは興味深い（Circulation 2001； $104: 1358)$. 